\title{
Small-scale Urbanism and Social Sustainability - Interdisciplinary Research of Public Space in Zagreb
}

\section{Jana Vukić}

University of Zagreb, Faculty of Social Sciences and Humanities, Department of Sociology, Croatia

e-mail: jana.vukic@ffzg.hr

\section{Tihomir Jukić}

University of Zagreb, Faculty of Architecture, Department of Urban Planning, Spatial Planning and Landscape Architecture, Croatia e-mail: tjukic@arhitekt.hr

\section{Ognjen Čaldarović}

University of Zagreb, Faculty of Social Sciences and Humanities, Department of Sociology, Croatia e-mail: ocaldaro@ffzg.hr

\begin{abstract}
Public space is the connecting tissue of a contemporary city, it is important for people's satisfaction with their city, overall quality of life, inclusiveness and social sustainability. This paper addresses the changes that transform contemporary cities and their public space, and using the example of interdisciplinary students' research of public space in Zagreb city-districts, shows the potential of small-scale projects and interventions regarding the issues of urban sustainability, quality of life and participation. Small-scale urbanism and interdisciplinary research of public space at city-district level emerged as important for the creation of a more sustainable city with adequate participation of citizens in the transformation of urban space. The quality of public space on city-district level is what people encounter on daily basis, so it is very important for overall satisfaction and quality of life. Big-scale urbanism should provide an
\end{abstract}


adequate network of public space, but small-scale urbanism and smaller interventions should be the main tool for a constant improvement of the quality of life based on local knowledge and every-day needs of citizens. Beside this, small-scale urbanism and an interdisciplinary approach to urban planning are important for the education of young professionals on space, namely architects and sociologists. It is still through an open dialogue between experts in different fields (social sciences and humanities and the technical field of architecture and urbanism) concerning public space, common good and social sustainability, that future experts should learn how to work in interdisciplinary teams on transformation of urban space in accordance with the local community.

Key words: public space, small-scale urbanism, interdisciplinary education, sustainability, participation.

Good architecture ensures good interaction between public space and public life. But while architects and urban planners have been dealing with space, the other side of the coin - life has often been forgotten.

Perhaps this is because it is considerably easier to work with and communicate about form and space, while life is ephemeral and therefore difficult to describe.

How to study Public Life? (2013) Gehl, Svarre

\section{Introduction}

Contemporary cities are very complex and ever-changing systems that are composed of the built environment and the people that live in it. In this system there are many individuals and differences, fragments of urban tissue and urban life, but there is one common denominator: public space as a common good. Looking at the contemporary cities through the lens of public space, commons and sustainability makes the big picture of such a complex system a bit clearer. It also brings together architects, urbanists and social scientists around the same quest: making cities a better place to live in. In this paper we wanted to stress two focuses of this quest: the first one is looking at the system (of the city) through the issue of sustainability (economic, ecological and social), and the second one is the focus on the common elements of the city (such as the public space) through interdisciplinary research, finding and implementing the solutions. To accomplish this, it is important to overcome the barriers that divide different disciplines dealing with the mentioned "built environment" and "city life", like architecture, urbanism and social sciences. In this paper we argue that it is important to begin with this crossing of disciplines among the students, as they are future experts, and the experience of working together in interdisciplinary teams may help them overcome the obstacles (Smagacz-Poziemska and Nóżka, 2018) they may encounter.

The beginning of the $21^{\text {st }}$ century is the time of constant and overall changes in all aspects of human life, including urbanization and urban development as well as 
science and experts dealing with it. Therefore, it is the time of questioning old concepts and finding new ones. In social sciences there is a strong focus on space and place and on the processes creating a new kind of space (and time) in the network society and the "dialectical opposition between the space offlows and space of place" (Castells, 2010:408). It has been 30 years now that Manuel Castells introduced the concept of informational mode of development, the concept of the space of flows and the Informational City (Castells, 1989), as a new urban form that emerged after the industrial city in "the new society, based upon knowledge, organized around networks, and partly made up of flows". The most important point that Castells made was that "the informational city is not a form but a process, a process characterized by the structural domination of the space of flows." (Castells, 2010:429). This was an important shift in the conceptualization of space and contemporary urban processes. It doesn't imply there is no urban form - the urban form of the third millennium according to Castells are mega-cities and their "distinctive feature of being globally connected and locally disconnected, physically and socially, that makes mega-cities a new urban form" (Castells, 2010:436). However, it emphasizes that there is significant change in the social structure (the network society). "The spatial articulation of dominant functions does take place in our societies in the network of interactions made possible by information technology devices. In this network, no place exists by itself, since the positions are defined by the exchange of flows in the network. Thus, the network of communication is the fundamental spatial configuration: places do not disappear, but their logic and their meaning become absorbed in the network." (Castells, 2010:443). Still, people live in places. However, their living conditions are very different and they are changing. "New technologies, by creating an artificial nearness and simultaneity between people, things and events, have destroyed the idea of proximity which was the base of urban construction and have produced a constant search for stability and appropriate distance." (Sepe, 2013:39). Not only technology is to blame for a constant change. Martina Löw stresses that the "pluralization and individualization - the hallmarks of modern societies - have resulted in a large variety of divergent interests and circumstances of life, which makes it difficult for urban planners to define shared values and common goals" (Löw, 2015:109). Löw points out the relational concept of space and proposes "to take greater account of the multiple, complex patterns of connections, interdependencies, frictions, disjunctures and mutual attachments in a highly diverse society." (Löw, 2015:118).

As the issue of sustainability is becoming ever more important in contemporary cities and their public space, we must acknowledge that a new approach to urban planning is needed for that reason, too. "Social sustainability is a subset of cultural sustainability; it includes the maintenance and preservation of social relations and meanings that reinforce cultural systems. Social sustainability specifically refers to maintaining and enhancing diverse histories, values, and relationships of contemporary populations." (Low, Taplin and Scheld, 2005:5). In this context, there is a need for a shift from older forms of city-planning to more dynamic ones. A comprehensive approach to public space and city-planning as a constant combining of two ap- 
proaches: top-down and bottom-up, both in planning and in participation ${ }^{1}$, allows the experts to take a new role, as Löw stresses "they no longer represent merely abstract technical expertise but become real mediators of conflicting interests" (Löw, 2015:111). In order to avoid conflicts or protests it is necessary that the experts and the local government are in touch with the people and the local perspective and knowledge. The experts need to implement this in plans and decisions to assure the stability of the chosen solution, because, as Berman points out, "the ability of governments and planners to efficiently (fairly and sustainably) plan the city is dependent on the availability of local knowledge" (Berman, 2017:7). Čaldarović and Šarinić also state that this approach reduces the potential refusal of space transformation and change in habits, or the so-called NIMBY (not in my backyard) syndrome (Čaldarović and Šarinić, 2017:57).

According to one of the most popular definitions, public space is a common space accessible to anyone at any given time of day or night, a space where people may satisfy their needs. Due to the different processes that were mentioned above, one of the main features of contemporary cities is the change in public space - its fragmentation, privatization (private or semi-private public spaces in shopping malls as substitutes for open public space, which is often perceived as insecure) and overall degradation. Public space is important for the city as it provides the opportunity for social mixing and interactions between different social groups and individuals (regardless of their material status or any other possible social differences). Nevertheless, today, the negative change in financing, the terrorism and other threats changed the nature of public space. Ali Madanipour points out that the "withdrawal from public space may be due to a fear of crime, mistrust of other social groups, and intensified social polarization. This withdrawal reflects in neglect and decline, poor maintenance, accumulation of waste and refuse, or lack of care and attention." (Madanipour, 2010:238). Doreen Massey in the book For Space (2005) wrote: "if time is to be open to a future of the new then space cannot be equated with the closures and horizontalities of representation. More generally, if time is to be open then space must be open too. Conceptualizing space as open, multiple and relational, unfinished and always becoming, is a prerequisite for history to be open and thus prerequisite, too, for possibility of politics." (Massey, 2005:59). More recently, Martina Löw in a book The Sociology of Space: Materiality, Social Structures, and Action (2016) has proposed to understand space as an "atmosphere" and a "meaningful horizon" created through "synthesizing in perception, memory and imagination" and "spacing as a process of placing and being placed" (Löw, 2016:167).

1 Top-down and bottom-up approaches correspond in general with two participation methods: unilateral (top-down) and collaborative (bottom-up). See also in: Čaldarović and Šarinić, 2017 and Berman, 2017. 


\section{Public space and its dynamics from the urban planning perspective}

Public space and public life have been important features of the cities throughout history. Today, public space is a symbol of inclusive, sustainable and creative European cities (per example, Vienna or Copenhagen), at the same time as Löw and Steets point out, the publicness became the basic category of sociology in Europe (Löw and Steets, 2014:214). The quality of public space is very important for the quality of life in urban areas. The survey Quality of Life in European Cities, implemented by the European Commission ${ }^{2}$, shows that people are very satisfied with the cities they live in (in all European cities at least $80 \%$ of people are satisfied that they live in their city). Based on the mentioned survey, the public space (markets, squares and pedestrian zones) of the City of Zagreb is regarded as positive by the people who took part in the survey. This puts Zagreb high on the list with $83 \%$ of satisfied people (of which 26\% is completely satisfied and $57 \%$ is relatively satisfied). However, around $15 \%$ of people are not satisfied. For the sake of comparison, the cities ranking higher on the list (above Zagreb) are Amsterdam, Helsinki, Ljubljana, Stockholm, Luxembourg and Vienna. ${ }^{3}$ Nevertheless, this does not mean that interventions and improvements are unnecessary. Various sociological research show different problems of public space in the City of Zagreb: an extreme commercialization and privatization in the city-center (Čaldarović and Šarinić, 2017; Čaldarović, 2011; Mišetić and Ursić, 2010; Svirčić, 2008) $)^{4}$, and problems of disordered and fragmented public space in other parts of the city (Čaldarović and Šarinić, 2017; Jukić et al. 2018). Another important finding is the problem of insufficient and inadequate citizens' participation in the decision-making processes (Mišetić, 2016; Čaldarović and Šarinić, 2017; Miletić, Ursić and Krnić, 2017; Zlatar, 2015). In order to improve the condition of public space and because of its complexity, an interdisciplinary approach is needed. Löw illustrates this complexity: "I assume one space with various components. This means that I oppose the division customary in sociology between a social and a material space which imputes that a space could emerge beyond the material world (social space) or that space could be perceived by human beings without a social pre-structuring of this perception (material space). Hence, in analysis I hypothesize a social space that is characterized by material and symbolic components." (Löw, 2016:6). This brings up the issue of understanding between different disciplines and the experts on space that becomes more and more important with the new urban conditions and a complicated role of mediation for the experts.

From an urbanist's point of view when discussing public space it usually implies a space enclosed by the surrounding constructions where street life takes place. However, there are more factors that influence the character and formation of public space, some of which are: road traffic, traffic at standstill, public transport, content

2 Quality of Life in European Cities 2015, Flash Eurobarometer 419

3 Table Satisfaction with public spaces in EU capital cities (p. 58) relating to the answer to Q1.6.

4 See also Knežević, Snješka. Zagreb u škarama (2018), Zagreb: UPI2M books.; Šimpraga, Saša. (2011). Zagreb, javni prostor. Zagreb: Porfirogenet. 
and activities in the public space, the content in the surrounding buildings. The timeline, that is, the stylistic features of the period during which a space was formed, gives public space a unique character, and it is directly connected to the style period of the surrounding architecture and the formation period, as well as the social and cultural characteristics. In addition, an important role in shaping and perceiving public space is played by its membrane, or the structure comprised of the elements of the constructed space, the height and volume of the architecture, as well as the interrelations and the formation of the local architecture (Horvat and Jukić, 2015).

Image 1

Characters important for public space: structure, communication, scale

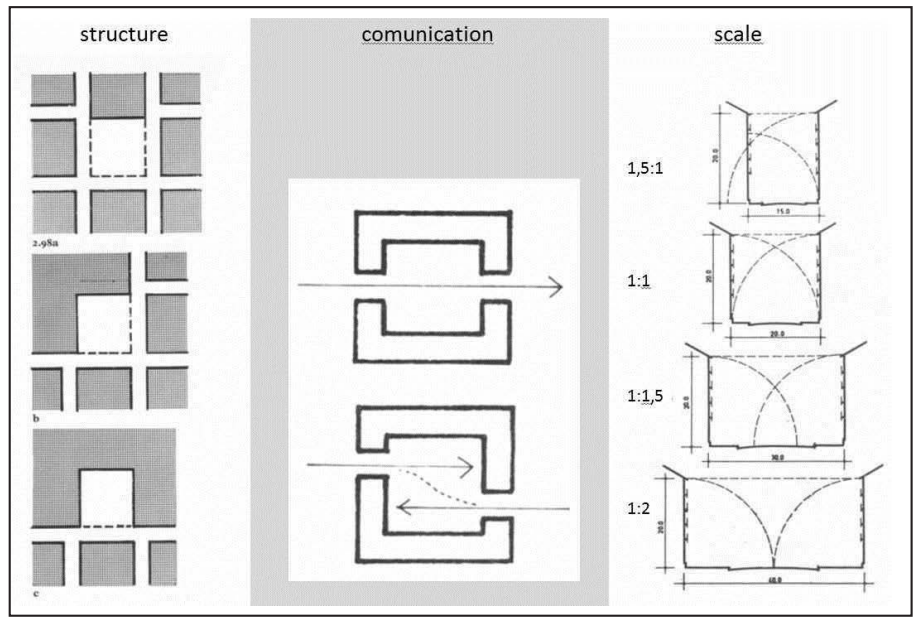

By employing different approaches to public space it is possible to discuss the human and the experience dimension of space and its perception. Public space can be experienced and perceived in different ways. It can be experienced when we walk, drive, stand or lie on it. It is also important how we perceive the space with our senses: smell, sight or by listening to the sounds it produces. The events taking place in public space also dictate the way we experience it. Our perception also depends on whether these events were positive or negative, whether a person would feel comfortable in a certain space depends on the activities taking place in this space, as well as its control and safety. The richness of public space and its quality in a city, city-district or neighborhood depends on the diversity and the number of different types of the public space (streets, squares, promenades, roads, parks, public stairwells or passages). Zagreb provides the best example. In the old part of the city (Donji grad - the central part from the $19^{\text {th }}$ century), it is possible to count dozens of different considerations of public space in terms of its format. However, the new part of Zagreb boasts only a few considerations of public space: a few squares and parks, lack of classic-type streets - they are more roads and the remainder is defined as other green surfaces or other non-built surfaces - spaces often without an identity or recognizability. If we compare Donji grad and Novi Zagreb, in terms of quantity Novi Zagreb has bigger public surfaces. In relation to the constructed part of the city, Donji grad, however, has fewer public surfaces. 
Image 2

Zagreb of the $19^{\text {th }} \mathrm{ct}$. and $2^{\text {nd }}$ part of the $20^{\text {th }} \mathrm{ct}$. - the relation between the built space and empty space in the city

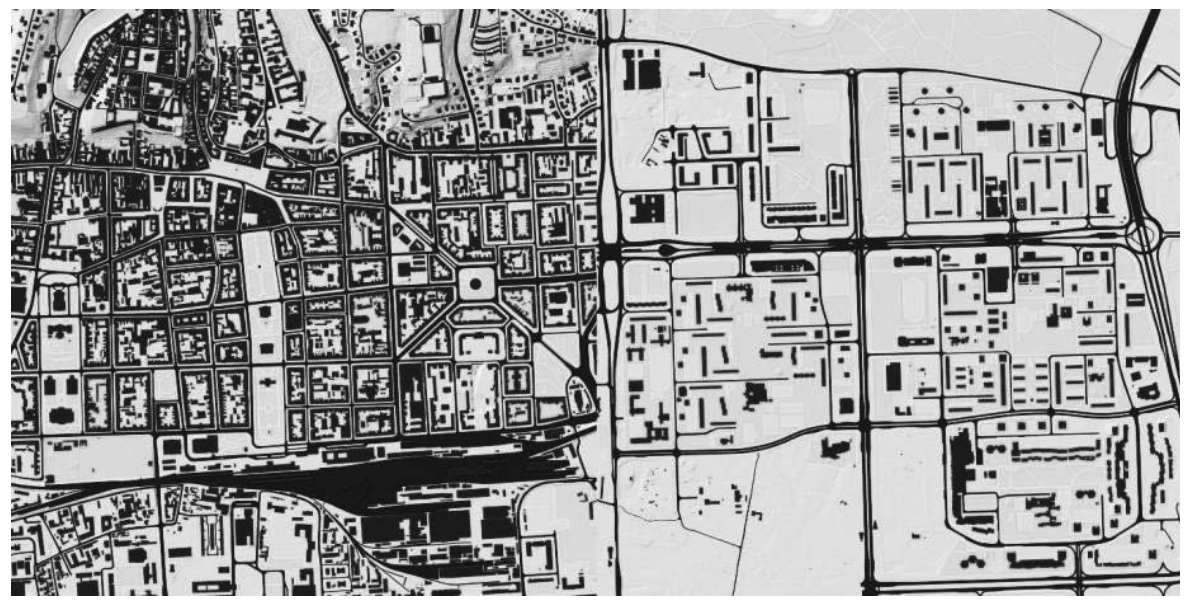

Source: https://geoportal.zagreb.hr/

The main features of public space have already been mentioned: accessibility to everyone, space available at any time (day or night) and space where people satisfy some of their (public) needs. However, it is also important to mention that when looking at a city or its smaller local part, there are three space categories: public space (streets, squares, parks); semi-public space, publicly owned space, or used by a specific group of people (i.e. inside part of a residential block); private space, accessible only to its owner (family-house yard). Concerning the use of space in relation to the ownership, there are various models. It is also visible that in some cases private space can be used for a public purpose (i.e. private park open to public, shopping malls, sport centers) and vice-versa.

Public space is also prone to changes through time, and this is discussed by the architects Jan Gehl and Brigitte Svarre: "Public life changes constantly in the course of a day, week, or month, and over the years. In addition, design, gender, age, financial resources, culture and many other factors determine how we use or do not use public space." (Gehl and Svarre, 2013:2). These changes are often related to space users and decision-making centers. As a result, there is economic and political influence on the one side, and profession and citizens on the other side. It is impossible to separate public open city spaces from public life, and they reconcile (or they should reconcile) and harmonize the economic and political influence with the opinion of the professionals and the wishes of the public.

In this context we can also analyze different activities related to public space and which can, considering the public space, manifest as:

- functional and structural transformations of the existing public surfaces

- planning and executing new public spaces

- connecting and networking one with the other. 
In urbanists' view it is precisely this "connecting and networking" which raises the quality of life and results in using the total public surface which is the sum of public surfaces of different intensities, significance and format. It does not only represent the sum, but also the unity of public space, which symbolically means much more than the sum itself. The more the network is complete and diversified, the more it allows movements in different directions and raises the quality.

However, this is not enough to create a sustainable city with a high level of residents' satisfaction with the quality of life. The architect Jan Gehl stresses that "for cities to achieve social sustainability, attempts must reach far beyond physical structures. If cities are to function, efforts must focus on all aspects from the physical environment and social institutions to the less obvious cultural aspects that have great significance on how we perceive individual quarters and entire city societies." (Gehl, 2010:109).

\section{Scales and approaches in urban planning: why is important to combine big and small scale as well as top-down and bottom-up urbanism}

Both scales in urbanism, the big-scale and the small-scale, as well as top-down and bottom-up approaches have their advantages and disadvantages, but when considered and implemented together - as a comprehensive approach to urban space transformation, they can display their best quality and provide a dynamic approach to urban reality that is needed in the light of its diversity and complexity. This approach provides a good basis for the implementation of different participation models in the decision-making process. When a space (i.e. city-district) is in the process of (trans)formation, it is important that its residents participate in the planning process, all other phases, as well as execution (spatial transformation). It is not an easy task, it has never been one, and today, with the plurality and social diversity in focus, it is even more complicated for urban planning experts to decide what the common interest is. In the age of complexity we can "but acknowledge that we are all interconnected and continually engage in a multitude of interactions and relationships, that we are in fact constituted by relationships in which gender, age, class, ethnicity, sexuality and nationality function as crucial markers that define that relation." (Löw, 2015:115). Löw stresses the advantage of the fact that "urban commons and the design of public spaces are subject to social negotiation processes between social groups" (Löw, 2015:122), and states that the experts can "fulfill the function of re-presenting the public interest not by seeking common consent or complying with the particular interest of a single social (sub)group" (Löw, 2015:119). An opportunity opens up "for creating new forms of cohesiveness based on the recognition of the crucial importance of social relations and interdependence" (Löw, 2015:117). We see it as a potential for more sustainable approach and more in line with Gehl's fundamental idea of cities for people. "Regardless of planning ideologies and economic prerequisites, careful management of the human dimension in all types of cities and urban areas should be a universal requirement." (Gehl, 2010:118)

In order to understand better the paradigm shift, two scales in urban planning and the corresponding methods of citizens' participation in the City of Zagreb will be explained briefly. 
It is important to review the two scales of planning and decision-making related to physical planning in general and especially for public spaces in the city to be able to keep track of the impact of different planning levels on the public space. General urban planning is a higher level of considering the urban space, than the implementation level. Top-down planning is long-term and it is realized at the level of the entire city or city-district (i.e. Zagreb General Urban Plan or Urban Development Plan for a city quarter). Well-being of the entire city is the starting point, in line with the adopted development strategy and the related plans or decisions for positioning the city in the region and the city's relation with its urban agglomeration. All the important segments for the city's normal functioning (considering the existing state and future development) are taken into account at the level of the city. Only one small segment, but not small in terms of its meaning, relates to the transformation of the existing public space and planning a new public space. This is specifically determined in the written part of the plan, in the so-called provisions for plan implementation.

Image 3

The most typical city planning model in history was the top-down model. This also determined public space as part of the city's identity (example of the communication matrix of Paris and Philadelphia)

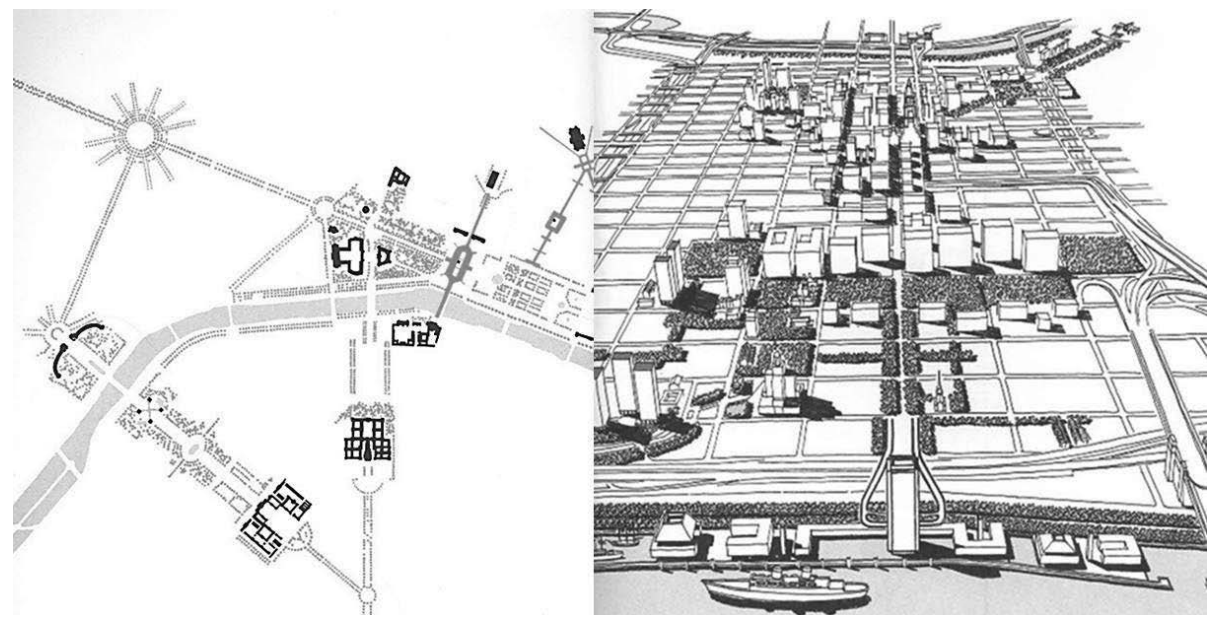

In this, citizens are included only in an unilateral procedure of plan presentation where they give suggestions and comments. However, the decision is made by the City Assembly. Therefore, the decision is made indirectly through a representative. Research shows that "unilateral procedures failed to uncover local knowledge and to incorporate local knowledge into plans, whereas collaborative deliberations succeeded." (Berman, 2017:3).

The second model is the bottom-up planning model of a character much closer to a residential neighborhood and local community, which as such has more influence on the appearance and functions of public space through local initiatives and actions. In general, the initiative for making changes in space come from the residents through the local community, and the realization process can be institutionalized or it can be 
implemented through smaller actions taken by the residents. It induces the collaborative public participation and respect for local dimensions in urban life (Čaldarović and Šarinić, 2017:55). The collaborative participation is based on reciprocity and cooperation and "it encourages acceptance and respect for local knowledge and fosters an understanding of professional planning knowledge" (Berman, 2017:4).

The bottom line is that the two approaches, the top-down and the bottom-up, in the new paradigm should be regarded at the level of their crossing-points. This approach has a potential for creating a more sustainable city, open to change according to the needs of the residents. Research show that, as Čaldarović and Šarinić point out, the combination of two approaches (top-down and bottom-up) has great advantages, namely: the "transparency of the planning process; affirmative attitude of the local community; good relation towards the space after the changes (connected to quality of life and the value of real estate etc.); knowledge needed for shaping the best urbanistic solution." (Čaldarović and Šarinić, 2017:58).

To explore the shift of paradigm to a more open concept of social negotiation of common interest (Löw, 2015) we will use the example of urban transformation at the city-district level. As it was mentioned already, the opportunities for interdisciplinary and cross-disciplinary cooperation open up at the city-district level (which is very suitable for interdisciplinary education). City-districts are very interesting subjects for research and planning, especially because both bottom-up and top-down planning levels are equally important here, and they both can and must include the local knowledge through active participation of the residents. Public space at citydistrict or neighborhood level is the obvious example of the public space which must meet the criteria and respect the city's general features (demands of a much greater scope than a residential neighborhood and a local community), and at the same time it must satisfy daily needs of the residents. All of the mentioned makes the studying and planning of public space at the small-scale the most interesting one for interdisciplinary education of future experts.

Image 4

City planning levels (entire city, city quarter, residential neighborhood) in relation to the top-down and bottom-up planning models

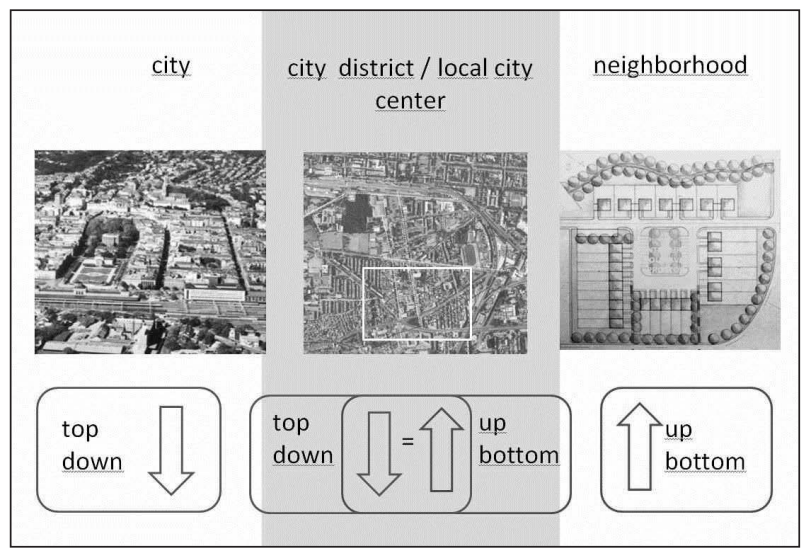


Educating future experts in the fields of architecture and urbanism in an interdisciplinary way and encouraging them to have (constant) dialogue with future social scientists proved to be a fruitful experience that improves their skills and broadens their views on city life. At the same time, this dialogue moves them as experts on space from their usual way of thinking (and learning) about its material or social (symbolic) component. At the end of the process, they must come up with solutions (plans, programs or improvement measures) that conceptualize space as material and symbolic at the same time.

As Mišetić and Ursić point out, in their research on public debate on the reconstruction of public space in the center of Zagreb (on the so-called Flower Square), there is a difference in the approach to city public space between expert actors. "Architects and sociologists, as experts in their fields who are interested in urban planning, often participate actively in discussions on public space planning. However, their notion of city is often very different. (...) Considering their discipline, interest in these issues is either from an architectural and urbanistic aspect or from a social sustainability point of view." (Mišetić and Ursić, 2010:9). Along this line of thought about the differences that make power relations in Zagreb (as in Croatia in general), between political and economic actors on the one side, and experts and citizens on the other, even more in favour of the first ones that already have too much power in decision making, interdisciplinary education and cooperation are very important. Sociologist Jelena Zlatar points out that the experts are well aware of that problem and the lack of interdisciplinary collaboration (Zlatar, 2013:171).

We must note once more that during the socialist period in Croatia (before 1990) the collaboration between urbanism and sociology was part of the planning procedure. It was obligatory to conduct social research on people's needs and implement those needs in urban planning. Today, the situation is very different, because of the dominating political and economic actors in liberal economy in Croatia with serious problems of democratic regulation (Svirčić Gotovac, 2008; Zlatar, 2015). Because of the weak position that both experts and citizens have in this situation we think it is important to encourage young architects and sociologists to cooperate and think about space in a creative, interdisciplinary and democratic way.

During the socialist period urban planning was a part of state politics, uniformed and interdisciplinary (Čaldarović, 1985), where different experts in planning in most of the cases where "agents" or empowered decision makers in their fields of expertise. Social ownership over the land in cities gave many possibilities to the state as a collective owner to organize centralized and long - term planning of urban areas. Sociologists have been in the position to "add" human dimensions to the already made urban plans, concerning mostly the housing conditions of the people in cities by analyzing the level of satisfaction of the inhabitants concerning the layout of the new settlements, the quality of housing units, buildings, apartments and the like.

After 1990, in the post-socialist period, new agents came into the field - a private entrepreneur who was able to reorganize the urban plans through his investments in separate buildings and not a comprehensive plan of the settlements or neighbor- 
hoods. So a new urban policy which will integrate multi-disciplinary approaches is necessary if urban planning should keep up with its real nature. The cooperation of architects, urban planners and social scientists is simply necessary.

\section{Examples of interdisciplinary education and research of public space in Zagreb}

In this chapter we will introduce some examples of productive interdisciplinary research of public space in Zagreb at city-district scale that were conducted in cooperation between the Department of Urban Planning, Spatial Planning and Landscape Architecture at the Faculty of Architecture, and the Department of Sociology at the Faculty of Humanities and Social Sciences. Both are members of the University of Zagreb. This educational model has been used through joint interdisciplinary workshops as part of a mandatory course City Transformation (2014-2018) ${ }^{5}$.

Image 5

The model of interdisciplinary education at the Faculty of Architecture

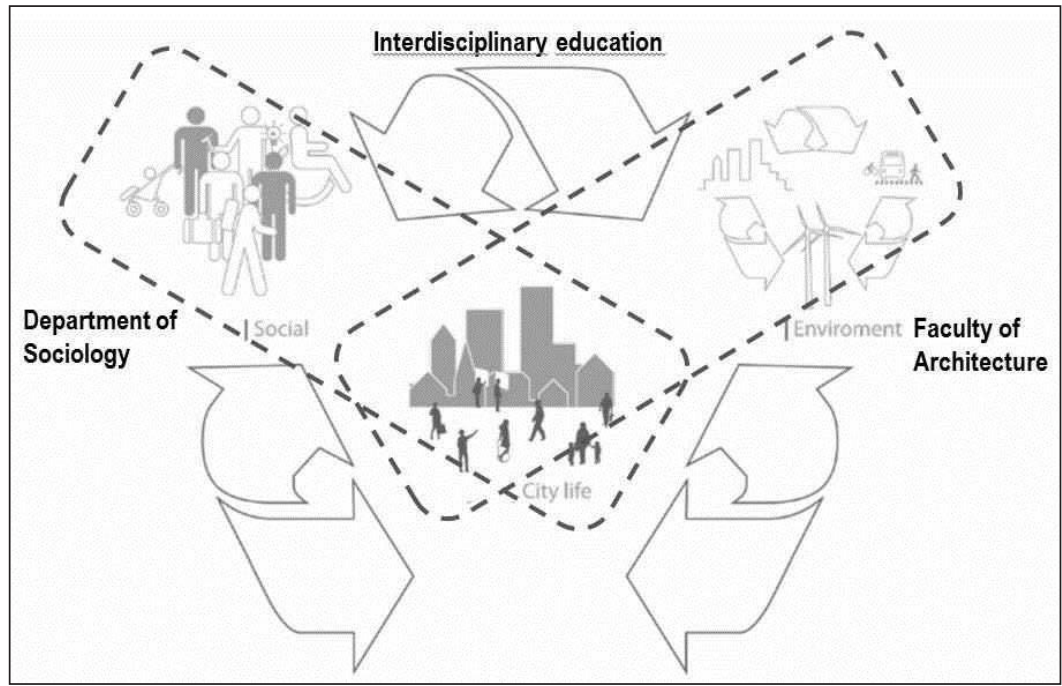

This kind of cooperation between disciplines (and faculties) opens up an opportunity for students to engage in interdisciplinary research of public space, open up the discussions and dialogue between different disciplines and (future) experts on space. All disciplines tend to "close up" and focus on their main field of interest, be-

5 The cooperation between urbanists and sociologists was initiated by professor Tihomir Jukić, Ph.D. (Faculty of Achitecture) and professor Ognjen Čaldarović, Ph.D. and Jana Vukić, Ph.D. (Faculty of Humanities and Social Sciences). The organization and execution of the course City Transformation has been allocated to the Department of Urban Planning, Spatial Planning and Landscape Architecture, Faculty of Architecture and the Department of Sociology, Faculty of Humanities and Social Sciences. 
ing it a material (for architects and urbanists) or a symbolic/social aspect (for social scientists) of the city-space. However, the interdisciplinary education and research through field work help to overcome the borders between the fields of study, in this case the technical disciplines and the social ones. The public spaces of selected citydistricts in Zagreb were analyzed according to the criteria of the quality of public space, focusing on both the architectural and social potentials of the public space. Students of sociology conducted research focusing mainly on the quality of life and the use of public space by different groups and local residents, while the students of architecture focused on the network of public space, connections and contents and the overall quality of built environment. Together they proposed the improvements and measures that could make the existing public space better, or they proposed a creation of a completely new public space if a need for such a transformation was recognized.

Image 6

Zagreb, urban transformation sites - selected locations (2014 - 2018)

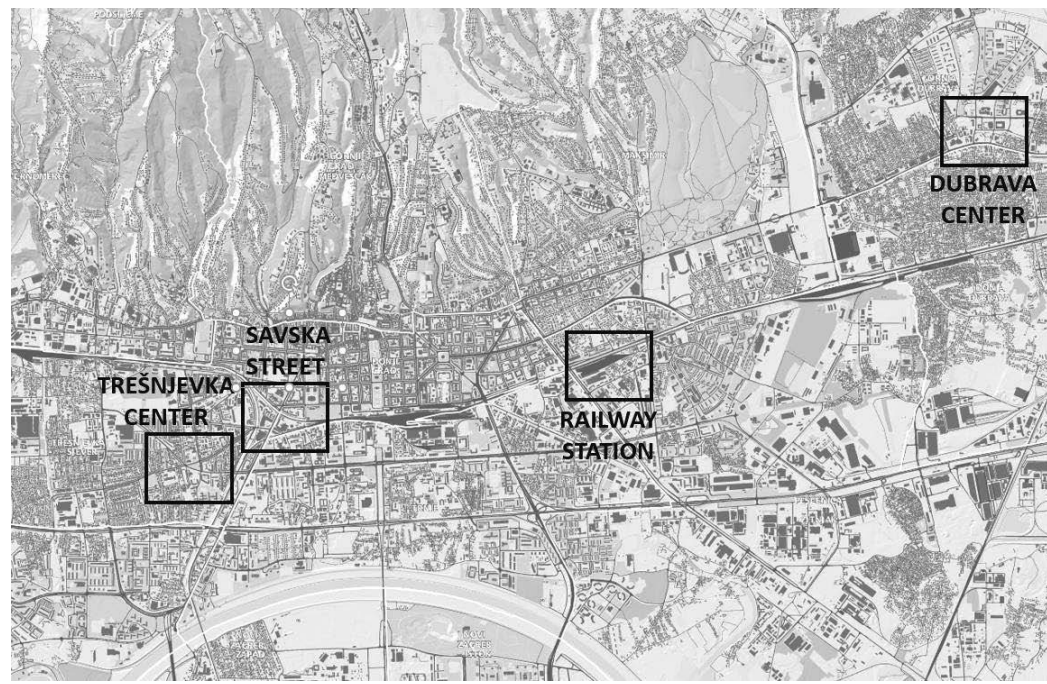

Source: https://geoportal.zagreb.hr/

The locations in the City of Zagreb were selected where it was possible to verify both planning levels (top-down and bottom-up), and research different aspects of the potential urban transformation of public space at city-district level (Jukić, 1998). The research included potential transformations of the centers of Zagreb's neighborhoods ${ }^{6}$ Trešnjevka, Dubrava and Peščenica, and a transformation of the neglected and fragmented public space at Savska Street, one of the main roads that connect

6 The research area does not correspond to the administrative divide of the City of Zagreb into 17 city-districts. It focused on Trešnjevka-sjever, Gornja Dubrava, Peščenica and the border space of Trešnjevka-sjever and Trnje city-districts, along Savska Street in Zagreb, but it included wider areas and neighbouring city-districts. 
the southern parts with the city-center. The main goal was to investigate the potential of developing the public space of city-district centers as elements important for the quality of life for residents and daily users. The transformation potential of the city centers was analyzed in the centers of Trešnjevka and Dubrava. ${ }^{7}$ Revitalization models based on sustainability, which could improve the quality of life and increase satisfaction of the residents and users of space without significant urbanistic interventions, were proposed.

\section{Image 7}

Dubrava, Zagreb - transformation of the neighborhood's center and the new public space of the local community (student Jana Horvat) and transformation of the city center along Savska Street (student Antonija Andelic)
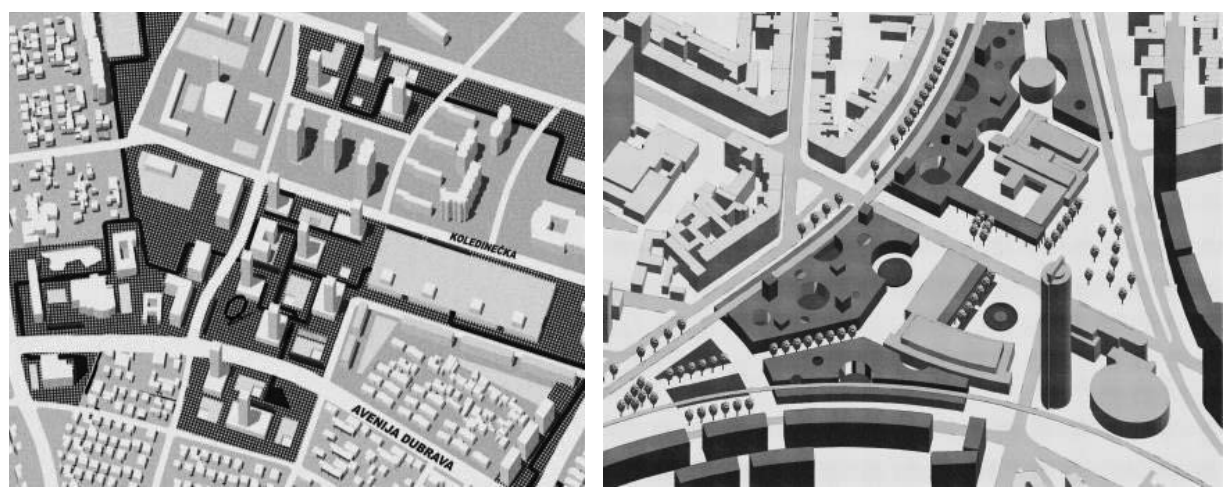

Another student's research task included a structural and content (trans)formation of the city center along Savska Street (Student center - Technical Museum - Cibona Center) as a new city public space connecting the city-center (city-districts Donji grad) and its immediate surroundings of Trešnjevka-sjever and Trnje city-districts, at the same time resolving the divide between them, formed mainly by transport barriers (railway track embankment). In the case of Peščenica city-district the theme was the transformation of the abandoned railway station (Istočni kolodvor) into a new public space and an intermodal transport terminal.

All interdisciplinary workshops were characterized by detailed research, conducted by students of Sociology, of the socio-demographic characteristics of local populations and the local identity. The results of the research were presented to the students of Architecture and Urbanism, and together they determined the programs, criteria and goals of space planning through work discussions. Students of Sociology

${ }^{7}$ Sociological research was conducted using qualitative research methods - interview, observations (with or without participation) and content analysis, on appropriate sample. Around 100 interviews were conducted in Dubrava (mainly structured or semi-structured and several in-depth ones) and two on-line surveys posted in Facebook groups (based on the research subject: using parks for children and using parks for dogs). Over 40 interviews were conducted in Trešnjevka (mainly semi-structured and a dozen of in-depth interviews). A total of 27 students participated in the research, mainly Sociology students from the Faculty of Humanities and Social Sciences in Zagreb. 
were also to comment on the projects of the urban transformation proposed by the students of Architecture. Each of the research projects ended with public presentations and an exhibition of the students' work at the faculty and in a city-district that was the subject of the urban transformation, so that the citizens could be informed about the entire project planned for their environment. Around 120 students participated in each of the projects, mentored by the professors from both of the faculties.

Image 8

Invitation to the exhibition of student work in Kulturni centar Dubrava with the Transformation of the Dubrava City Center as the main theme

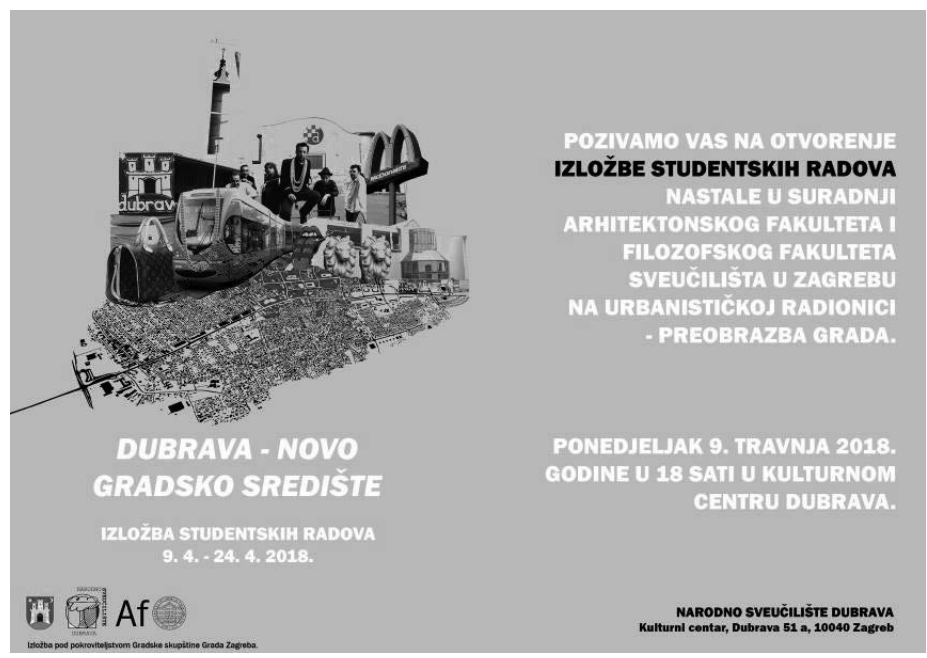

The education of future experts who will perform practical work in public spaces (architects and urbanists) gives a lot of attention to public space at the level of small-scale urbanism, not only through mandatory courses at college. Teaching and education in the area of public space is implemented in five different ways and levels at the Faculty of Architecture in Zagreb in cooperation with experts from the Department of Sociology of the Faculty of Humanities and Social Sciences ${ }^{8}$ a mandatory course, full semester (workshop + research + fieldwork), elective course, doctoral study (The potential of public space transformation - quality criteria and social and symbolic characteristics), scientific research project (Development poten-

8 Another example is the Summer workshop City Public Spaces - tradition and contemporary needs (Zadar, 2017) organized by the Faculty of Architecture in Zagreb and the University in Zadar. The present is characterized by disordered residential building, squalor and lack of planning of new public spaces, so the interdisciplinary summer school was supposed to motivate the transformation of the existing public spaces in the city center and its surroundings. Also, the summer school was focused on the need for developing the existing public spaces and planning new ones in Zadar, at least at the level of each city-district, so that the residents could identify themselves with the space they live in (Jukić, 2017). The focus of the summer workshop was directed at researching traditional, contemporary, physical, symbolical and infrastructural potentials of the space, and to suggest project ideas intended for the local community with active participation of the residents throughout the entire process. 
tial of the public space of Croatian cities) ${ }^{9}$ and the summer school (interdisciplinary education, fieldwork with local community participation). Therefore, we can conclude that despite the situation on the level of decision-making, local government and a devastating practice of privatization and devastation of public space in Zagreb, there are lots of opportunities to improve the state of built environment through the interdisciplinary education of experts on public space.

\section{Conclusion}

The planning of public space and city-space in general should be based on paying attention equally to the material space of the city as well as the social life and the people who live in the city. Only by comprehensive planning at different scales and levels (city, district, neighborhood) with the participation of local residents and citizens in general, the city can obtain a high quality of public space and a high level of user satisfaction. On the level of city-districts and neighborhoods the process of space transformation should be comprised of a continuous dialogue of experts with the local community about their needs and small-scale interventions. This should be based on the concept of the city as a network of public space that should be flexible, open and multifunctional to better meet the needs and expectations of its residents and future generations and in a more sustainable manner. To achieve this goal, it is important to use an interdisciplinary and comprehensive approach to urbanism and maintain constant dialogue between different urban actors, but also between different experts on space.

The main focus of urban planning and urban interventions should always be on the citizens and their participation in the decision-making process at all scales and levels, especially at the level of every-day use of the public space of the city. Wellplanned and conceptualized public space is inviting to the people, to use Gehl's words - it is calling for the interaction. "If there are many people, or if something is going on, more people and more events tend to join in, and the activities grow both in scope and duration." (Gehl, 2011:73).

To achieve a flexible and interdisciplinary approach in urban planning and urban transformation, experience is needed, and it should begin as a part of faculty training for the future experts who will in some way participate in its design, formation and use. For architects and urbanists it is very important to highlight the social sustainability and the social element of public space at the level of its planning and use, and in both top-down and bottom-up approaches in public space planning.

9 The goal of the Development potential of the public space of the Croatian cities research project is to determine the state of the public space, its development potential and to set guidelines for its transformation. Based on these examples from continental and coastal city structures, the state of the public space will be investigated. This will result in elements for a more systematic insight into the problems and development potentials of the present public space as an important factor of sociality and promotion of democracy. In the research, special attention is dedicated to the system of planning and designing the public space. 
The example of the interdisciplinary research conducted with the students of two faculties (Faculty of Architecture and Faculty of Social Sciences and Humanities in Zagreb) shows that a dialogue of professions is useful. This dialogue helps experts to avoid an incomplete consideration of public space, at the same time both material and symbolical. It also points out that space is not only a container for social interactions and relations of power, but also that there is "no social phenomenon free of space" (Löw, 2016:x). It allows students to experience and research "how various dimensions of the social are structured by means of which spaces (including overlapping spaces) and how these spaces are reproduced, whether intentionally or routinely, in everyday action." (Löw, 2016:x).

Bringing up the sustainability issue and improving the public space of contemporary cities is crucial for the better future (the one without the protests and misunderstanding between the different actors in urban space), but it can be achieved only through interdisciplinary cooperation and a combination of long-term planning and smallscale interventions. It should be based on the comprehensive approach to urban planning that is combining the top-down and bottom-up approaches with different and flexible forms of public participation in urban planning and decision making.

\section{References}

1. Berman, T. (2017). Public Participation as a Tool for Integrating Local Knowledge into Spatial Planning. Planning, Participation, and Knowledge. Springer.

2. Castells, M. (2010). The Rise of the Network Society. $2^{\text {nd }}$ edition. Wiley-Blackwell.

3. Castells, M. (1989). The Informational City. Information Technology, Economic Restructuring, and the Urban-Regional Process. Basil Blackwell.

4. Čaldrović, O. (1985). Urbana sociologija - socijalna teorija $i$ urbano pitanje=Urban sociology - social theory and the urban question. Zagreb: Globus, 221-248.

5. Čaldarović, O. (2011). Urbano društvo na početku 21. stoljeća. Osnovni sociološki procesi $i$ dileme. $=$ Urban society at the beginning of 21st century. Zagreb: Jesenski i Turk, 119-168.

6. Čaldarović, O. i Šarinić, J. (2017). Suvremeni grad. Javni prostori i kultura živlinja - primjer Zagreba = Conemporary City: Public space and culture of living - the example of Zagreb. Zagreb: Jesenski i Turk.

7. European Commission (2016). Quality of Life in European Cities 2015, Flash Euro barometer 419. http://ec.europa.eu/regional policy/sources/docgener/ studies/pdf/urban/survey2015 en.pdf. (Pregledano 13.3.2018.)

8. Gehl, J. and Svarre, B. (2013). How to study Public Life? Island Press, 2.

9. Gehl, J. (2011). Life Between Buildings. Using Public Space. Island Press.

10. Gehl, J. (2010). Cities for People. Washington: Island Press.

11. Gehl Architects. https://gehlpeople.com/

12. Horvat, J. and Jukić, T. (2015). Zagreb - Public Space „Somewhere in Between: Contribution to the Deliberation of Planning and Selection of Locations and Public Space Design. Projects for an Inclusive City, in: Marina, Ognen and Armando, Alessandro (eds.). Projects for an Inclusive City - Social integration through Urban Growth Strategies. Skopje: City of Skopje, Macedonia, 158-167. 
13. Jukić, T.; Vukić, J.; Vukić, F.; Podnar, I. (2018). Javni prostor središta Trešnjevke i Dubrave u Zagrebu. - Kriteriji kvalitete i modeli preobrazbe (Public Spaces in Zagreb Districts Trešnjevka and Dubrava - Quality criteria and transformation models). Prostor, 26 (218) 1-55: 95-105.

14. Jukić, T. (1998). Povijesno - urbanistička studija preobrazbe "Stare Trešnjevke". Zavod za planiranje grada Zagreba.

15. Jukić, T. (2017). Revitalizacija javnog prostora lokalne zajednice u turističkom / povijesnom gradu, u: Jukić, T. (Ur.). Javni prostori grada - tradicija $i$ suvremene potrebe (City Public Spaces - Tradition and Contemporary Needs). Zagreb: Sveučilište u Zagrebu, Arhitektonski fakultet ; Sveučilište u Zadru: 16-19.

16. Löw, M. and Steets, S. (2014). The spatial turn and the sociology of built environment, in: Routledge Handbook of European Sociology Routledge. https:// www.routledgehandbooks.com/doi/10.4324/9780203814956.ch13. (Pregledano 3.12.2015.)

17. Löw, M. (2015). Managing the Urban Commons. Public interest and the representation of interconnectedness, in: Borch, C. and Kornberger, M. (Eds.). Urban Commons. Rethinking the City. Routledge, 109-126.

18. Löw, M. (2016). The Sociology of Space: Materiality, Social Structures, and Action. Palgrave Macmillan.

19. Low, S.; Taplin, D. and Scheld, S. (2005). Public Space E Cultural Diversity. Austin: The University of Texas Press.

20. Madanipour, A. (Ed.) (2010). Whose Public Space? International case studies in urban design and development. Routledge, 237-242.

21. Marling, G. and Juul, H. (2007). The Danish provincial towns have acquired new and beautiful urban spaces - but are they sufficiently dynamic?. http://www. byensrum.dk/english/documents/Marling_Juul_030907_eng.pdf.

22. Massey, D. (2005). For Space. Sage Publications Ltd., 9-15; 55-60.

23. Miletić, G.-M.; Ursić, S. i Krnić, R. (2017). Sekundarno stanovanje i upravljanje lokalnim razvojem: lokalni društveni odnosi kao odrednica participacije stalnih i povremenih stanovnika u procesu planiranja razvoja (Second Homes and the Management of Local Development: Local Social Relations as a Predictor of Permanent and Temporary Residents' Participation in the Development Planning Process). Revija za sociologiju, 47 (3): 303-334.

24. Mišetić, A. i Ursić, S. (2010). 'The Right to the City': An Example of a Struggle to Preserve Urban Identity in Zagreb. Sociologija i prostor, 48 1(186): 3-18.

25. Mišetić, A. (2016). Društveni aspekti urbane regeneracije: participacija i koncept socijalne održivosti (Social aspects of urban regeneration: participation and the concept of social sustanability), u: Koralet, A. (Ur.). Strategije urbane regeneracije. = Strategies of urban regeneration. Zagreb: Hrvatski zavod za prostorno uredenje, 298-305.

26. Sepe, M. (2013). Planning and Place in the City: Mapping place identity. Routledge, xiii-xviii; 3-43; 298-304.

27. Smagacz-Poziemska, M. and Nóżka, M. (2018). Architects and Designers Meet Sociologists to Design Urban Space. Reflections on the (im)possible crossing of disciplinary borders. Societas/Communitas, 1-1 (25-1).

28. Svirčić Gotovac, A. (2008). Akteri rekonstrukcije Cvjetnoga trga u Zagrebu (Actors of the Flower Square reconstruction in Zagreb). Sociologija i prostor, 461 (179): 53-76. 
29. Zlatar, J. (2015). The Quality of Housing at the Subjective Level: Aesthetic and Ecological Aspects of the Neighbourhood and Citizen Participation, in: Svirčić Gotovac, A. i Zlatar, J. (Eds.). The Quality of Living in New Housing Estates in the Settlement Network of Zagreb. Zagreb: IDIZ, 75-114.

30. Zlatar, J. (2013). Urbane transformacije suvremenog Zagreba. Sociološka analiza. = Urban transformations of contemporary Zagreb. Sociological analysis. Zagreb: Plejada; IDIZ, 151-184. 
Izvorni znanstveni rad

Jana Vukić

Filozofski fakultet Sveučilišta u Zagrebu, Odsjek za sociologiju, Hrvatska

e-mail: jana.vukic@ffzg.hr

Tihomir Jukić

Sveučilište u Zagrebu, Arhitektonski fakultet, Zavod za urbanizam, prostorno planiranje i pejsažnu

arhitekturu, Hrvatska

e-mail: tjukic@arhitekt.hr

ognjen Čaldarović

Filozofski fakultet Sveučilišta u Zagrebu, Odsjek za sociologiju, Hrvatska

e-mail: ocaldaro@ffzg.hr

\section{Urbanizam malog mjerila i društvena održivost - Interdisciplinarno istraživanje javnog prostora u Zagrebu}

\section{Sažetak}

Javni prostor vezivno je tkivo suvremenoga grada te važan čimbenik zadovoljstva stanovnika svojim gradom, općom kvalitetom života, inkluzivnošću i društvenom održivošću. Ovaj rad istražuje promjene koje transformiraju suvremene gradove i njihove javne prostore te na primjeru interdisciplinarnog studentskog istraživanja javnog prostora u zagrebačkim gradskim četvrtima pokazuje potencijal projekata i intervencija malih razmjera u rješavanju pitanja urbane održivosti, kvalitete života i participacije. Urbanizam malog mjerila i interdisciplinarno istraživanje javnog prostora na razini gradske četvrti javlja se kao važan element stvaranja održivijeg grada u kojem građani adekvatno participiraju u transformaciji urbanog prostora. Kvaliteta javnog prostora na razini gradske četvrti je nešto s čime se stanovnici susreću svakoga dana, pa je vrlo bitna za ukupno zadovoljstvo i kvalitetu života. Urbanizam velikog mjerila trebao bi omogućiti stvaranje adekvatne mreže javnog prostora, no urbanizam malog mjerila i manje intervencije trebale bi biti glavno sredstvo stalnog poboljšanja kvalitete života temeljeći se na lokalnom znanju i svakodnevnim potrebama građana. Osim toga, urbanizam malog mjerila i interdisciplinarni pristup urbanom planiranju važni su za obrazovanje mladih stručnjaka za prostor, odnosno arhitekata i sociologa. Upravo bi kroz otvoren dijalog između stručnjaka iz različitih područja (društvenih i humanističkih znanosti te tehničkog područja arhitekture i urbanizma) o temama javnog prostora, zajedničkog dobra i društvene održivosti budući stručnjaci trebali učiti kako raditi u interdisciplinarnim timovima na transformaciji urbanog prostora u skladu s lokalnom zajednicom.

Ključne riječi: javni prostor, urbanizam malog mjerila, interdisciplinarno obrazovanje, održivost, participacija. 